\title{
The Madagascar rosewood massacre
}

\author{
Derek Schuurman and Porter P. Lowry II'
}

\author{
Correspondence: \\ Derek Schuurman \\ E-mail: derekschuurman7@yahoo.co.uk
}

\begin{abstract}
Valuable timber has been exploited from Madagascar's rainforests for many decades, and Malagasy rosewood and palissandre (Dalbergia spp.) are among the most sought after hardwoods in the world. Large quantities have been harvested and exported at an increasing rate over the last decade, almost entirely from illegal logging in protected areas, in particular Masoala and Marojejy National Parks, which comprise part of the newly-established Atsinanana UNESCO World Heritage Site in the SAVA (Sambava - Antalaha - Vohémar - Andapa) region of northeast Madagascar. We present information obtained from sources in the region that documents an unprecedented, highly organized expansion in the illegal timber trade operating openly in the wake of the country's current political turmoil, with more than 625 containers of rosewood worth an estimated US \$ 130 million leaving just from the port of Vohémar (Iharana) since early 2009 to cater for the demand of the international market. Members of local communities around Masoala and Marojejy derive very little benefit from timber harvesting, which severely compromises the integrity of the protected areas and their ecosystems, while nearly all the profits go to those who run the illegal operations. Income from ecotourism and other potential benefits is limited at Masoala and Marojejy by the region's climate, relative inaccessibility and poor infrastructure, making it nearly impossible for locals to resist short-term gains from forest exploitation. Insufficient in numbers and lacking authority, park staff are unable to effect any control over logging activity within protected areas. The current scramble for resources in Madagascar's parks and reserves challenges the viability of the previous government's plans to protect $10 \%$ of the country and calls into question the conservation commitment of the current regime.
\end{abstract}

\section{RÉSUMÉ}

Les bois précieux de Madagascar ont fait l'objet d'une exploitation forestière pendant de nombreuses années en portant notamment sur l'ébène (Diospyros spp.), le bois de rose et le palissandre (Dalbergia spp.) qui font partie des essences les plus prisées au monde. D'importants volumes de bois précieux ont ainsi été exportés avec une augmentation exponentielle au cours de la dernière décennie passant de quelques centaines de tonnes par mois en 1998 à plus de 30,000 tonnes entre juillet 2000 et juin 2001. Ces bois précieux ont presque tous été obtenus d'une exploitation illicite en provenant des aires protégées et plus particulièrement des Parcs Nationaux de Marojejy et de Masoala dans la région SAVA (SambavaAntalaha - Vohémar - Andapa) au nord-est de Madagascar. Ces parcs ont été récemment reconnus au titre de patrimoine mondial de I'UNESCO dans la nouvelle région des forêts humides de l'Atsinanana. Nous présentons des informations obtenues de sources régionales qui montrent qu'une organisation d'un trafic sans précédent de l'exploitation illégale dans les aires protégées s'est mise en place au moment de la crise politique qui a commencé dans le pays au début de 2009 avec l'exportation de 625 conteneurs d'une valeur estimée de US \$ 130 millions du seul port de Vohémar (Iharana), pour couvrir la demande du marché international. Les membres des communautés villageoises limitrophes des parcs de Masoala et de Marojejy ont peu profité de la manne que représente l'exportation de ce bois précieux qui compromet par ailleurs l'intégrité des zones protégées et leurs écosystèmes alors que la quasi-totalité des gains va à ceux qui organisent le trafic. Les revenus de l'écotourisme et d'autres activités sont limités aussi bien dans les parcs de Masoala que du Marojejy par le climat de la région, I'inaccessibilité relative et des infrastructures modestes qui font qu'il est difficile aux gens de la région de résister aux gains à court terme de l'exploitation forestière car elle représente leur seule bouée de sauvetage en cas de crise, qu'il s'agisse d'un cyclone saisonnier ou d'une crise politique comme celle de 2009, d'autant que les agents des parcs n'ont pas les moyens de s'y opposer et ne sont pas assez nombreux. La course actuelle aux ressources des parcs et réserves de Madagascar compromet la légitimité et la viabilité du plan de l'ancien gouvernement de protéger $10 \%$ du pays et remet en cause l'engagement pour la protection de la nature du régime actuel.

KEYWORDS: Illegal logging, rosewood, ebony, Dalbergia, Diospyros.

MOTS CLEF : exploitation forestière illégale, bois de rose, palissandre, ébène, Dalbergia, Diospyros. 


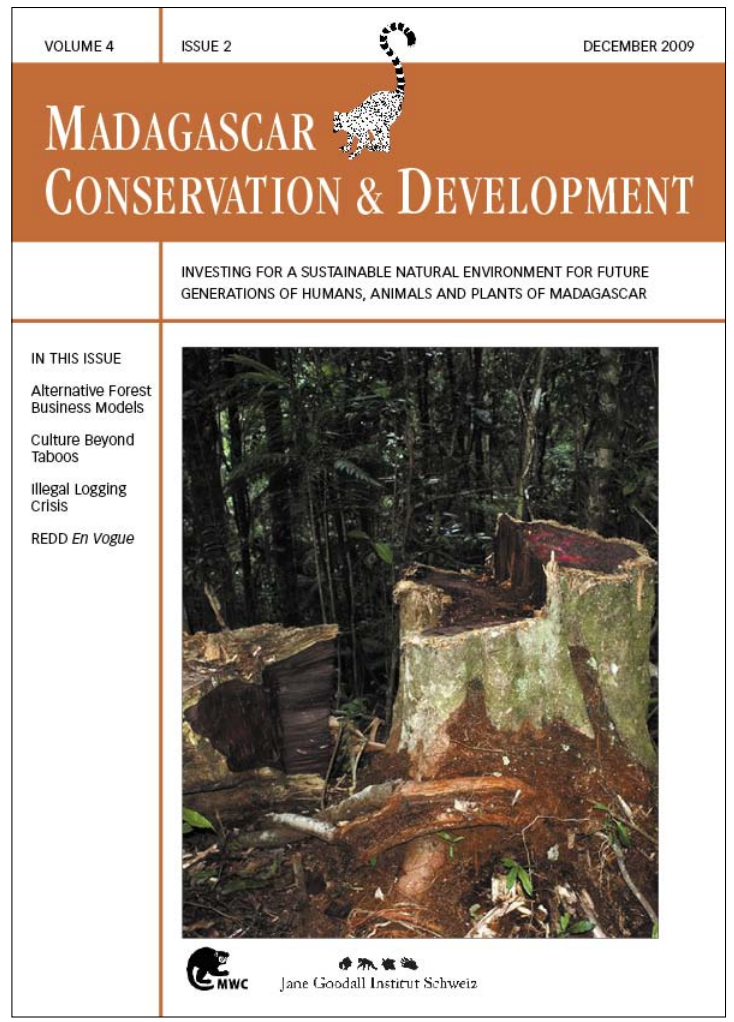

Madagascar Conservation \& Development is the journal of Madagascar Wildlife Conservation (MWC) and the Jane Goodall Institute (JGI Switzerland). It is produced in these institutions' own responsibility.

All the Issues and articles are freely available at http://www.mwc-info.net/en/services/journal.htm

Contact Journal MCD

info@journalmcd.net for general inquiries MCD funding@journalmcd.net for supporting the journal

Journal Madagascar Conservation \& Development Institute and Museum of Anthropology University of Zurich

Winterthurerstrasse 190

$\mathrm{CH}-8057$ Zurich, Switzerland

contact@mwc-info.net for general inquiries

Postfach 2701

CH-8021 Zürich, Switzerland

Logement 11, Cité Andohaniato

Antananarivo 101, Madagascar

info@janegoodall.ch for general inquiries JG

$2 \pi \approx$

Jane Goodall Institut Schweiz
Jane Goodall Institute Schweiz

Postfach 2807

8033 Zürich

switzerland 


\section{INTRODUCTION}

Madagascar's forests have long been under intense and rapidly increasing pressure from various sectors of society, including members of impoverished communities living around protected areas and well organized criminal networks with extensive international links. Over the last few years, this pressure has reached unprecedented levels and is having an immense, unsustainable and in many cases irreversible impact on some of the country's most vulnerable ecosystems.

Madagascar's botanical diversity is exceptionally high, with an estimated 13-14,000 species of vascular plants, a majority of which occur in forest habitats, and more than $90 \%$ of which occur nowhere else on earth (Phillipson et al. 2006). Some of the island's tree species have a high commercial value, in particular the rosewoods and palissandres (members of the genus Dalbergia L. f., Fabaceae) and ebonies (Diospyros L., Ebenaceae) (Wilmé et al. 2009). Dalbergia includes 48 currently recognized species in Madagascar (Bosser and Rabevohitra 1996, 2005, Du Puy et al. 2002), and Diospyros has ca. 85 recognised Mala gasy species, with nearly twice as many still unnamed (Schatz 2001, Schatz in litt.). Despite recent taxonomic work on these important groups, very little is known about their biology and ecology, and the details of their classification remain poorly understood and largely inaccessible to those working in the forestry sector. Moreover, the efforts of scientists and conservationists to educate local people about the value of living trees and intact forests have been hampered, while in contrast, local community members are acutely aware of the commercial value of these tree species in the form of cut wood. Vernacular names provide a clue to this division: For example 'rosewood' and palissandre are clearly distinguishable by those involved in any aspect of forestry or in the timber trade (Schatz 2001, Stasse 2002) despite representing members of a single well-delimited and widely recognised genus. The conservation significance of valuable hardwoods has received scant investigative attention in Madagascar, with rare exceptions such as those focussed on the western coastal region(Ganzhorn and Sorg 1996).

Logging in Madagascar has been regularly documented over the decades but legislation pertaining to the organised export of precious timber has never been reported on in depth. Nor has it received sufficient interest from international conservation and development agencies in the context of measuring the current level of timber harvesting and the volume of wood exported, and, to assess whether these levels are sustainable.

According to André Peyrieras (in litt.), when precious timber was exploited during the colonial period (1896-1960), some of the most sought-after palissandre was exported from Madagascar to Le Havre, France. From there, it was sent on to Brazil and subsequently returned to France under the label 'Palissandre de Rio' (a trade name for Dalbergia nigra, incidentally the only species in the genus currently protected under CITES). Peyrieras also noted that the particularly alluring wood of certain Dalbergia species found on Montagne d'Ambre in northern Madagascar was sent to France, where it was made into furniture marketed as 'False Rosewood'. Significantly Peyrieras pointed out that rosewood originating from the areas around Sambava, Andapa and Antalaha was regarded as being of poor quality because it was difficult to work with and was therefore less valuable. He indicated that the highest quality rosewood came from the southern half of the Masoala
Peninsula, where precious wood was exploited extensively in the 1960s in accessible places below 400-500m in elevation.

There has Iong been an understanding among local authorities that legislation relating to these precious sources of timber is a complex matter, and the status of its export has oscillated between outright bans, the first of which dates back to 1975 (Ballet and Rahaga 2009), followed by periodic exceptions. In 2000, the Government of Madagascar adopted a decree to stop the export of precious timber from October 2000 for three years (decree N. 11832 / 2000). Existing permits were still considered valid, but with certain conditions attached, such as the prohibiting of exporting any unprocessed wood. The quantity of timber exported since, however, is said to be substantial, although statistics appear to have remained in the possession of the Ministry of Water and Forests. Findings from in-depth studies conducted on the subject remain in grey literature, for example the unpublished report by Stasse (2002) detailing the investigation she conducted.

The 2000 decree allowed for the exporting of 10,000 tons of rosewood which was considered to be 'felled by cyclones'. The decree also permitted exporting of rosewood, which had been harvested before cyclones - a quantity which local authorities in the SAVA region put at approximately 25,000 tons. This rosewood had to be moved to Toamasina by 30 June 2001 and exported by 30 september 2001, but according to research by Stasse in 2002, only some 7,900 of the 10,000 tons of timber had actually reached Toamasina in time.

In this paper we aim to provide an overview of the nature, and where appropriate the history of the predicament facing some of Madagascar's protected areas, which are under extreme pressure from illegal timber exploitation that is thriving in the chaos of Madagascar's current political situation.

\section{METHODS}

Information has primarily been gathered in the SAVA region in north-eastern Madagascar, where precious timber has been sourced for decades from rainforests, including a network of protected areas designated as the Atsinanana UNESCO World Heritage Site in 2007 (Figure 1). For this article, reliable, wellplaced sources collected photographs of illegal exploitation and transportation of harvested trees and of shipping documents detailing a burgeoning trade in illegally-sourced timber, which are also presented in a poster prepared for the World Forestry Congress held in Buenos Aires, Argentina, 18-23 October 2009 (Wilmé et al. 2009, see Supplementary Material). We also used sources from the grey literature (in particular Stasse 2002, cited in Ormsby and Kaplin 2005) and recently released reports (e.g., Ballet and Rahaga 2009).

\section{RESULTS AND DISCUSSION}

The data we have compiled for the present study on the export of precious timber includes some astonishing revelations:

- The number of logs of precious timber exported monthly from the port of Toamasina increased from 332 in 1998 to 4,108 in 2000.

- $\quad$ Between 2002 and 2009 logging of rosewood was strictly forbidden in any protected areas. However, according to unpublished reports by wCS, logging was happening in Masoala National Park and also in Marojejy (Patel 2007). 


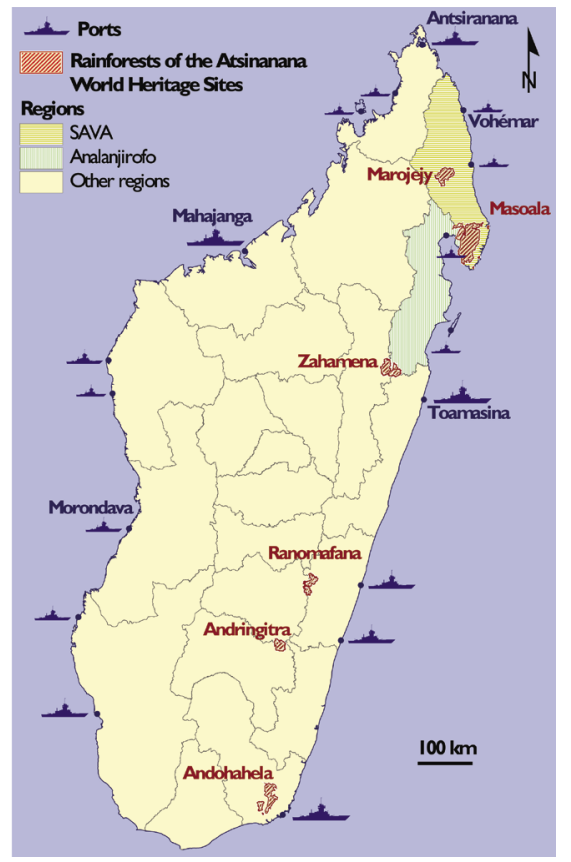

FIGURE 1. The six National Parks included in Atsinanana UNESCO World Heritage Sites, the SAVA and Analanjirofo regions in Northeastern Madagascar, and the ports along Madagascar coasts.

- Research published by Kozak and Canby (2007) reveals that China is purchasing vast quantities of unprocessed timber from various countries. This is also alluded to in Goldstein et al. (2006).

- If we consider evidence such as numerous shipping documents detailing rosewood shipments from Vohémar in particular during 2009 it is clear that the bulk of the illegally-sourced rosewood was shipped to several Chinese ports. This assertion is supported by Stasse (2002) and Razafindramiadana (2009). The rosewood stock extracted from the SAVA region and exported from Vohémar can be estimated at 17,194 tons of wood between July 2000 and June 2001 with an approximate number of trees felled at ca. 43,500. These respective numbers have been estimated for the Analanjirofo region with exporting from Toamasina of 14,284 tons of wood or 36,500 trees for the same period (Table 1).

- The timber exported from Toamasina in 2001 originated mainly from the Masoala Peninsula, including Masoala National Park, but also from Marojejy National Park (Stasse 2002).

- A total number of 571 containers of rosewood, worth an estimated US \$ 120 million, was exported between late January and the end of April 2009 (Wilmé et al. 2009).

- Another shipment of 55 containers (containing ca. US\$ 11.5 million worth of wood) was assembled and exported to China on 31 October 2009 (Table 2, Maka 2009).

Illegal logging of rosewood in Masoala National Park is widespread and involves individuals from communities surrounding much of the park, as reported by Ormsby and Kaplin (2005). Interviews conducted for their study indicated that people have benefited from a variety of illegal activities, particularly lemur hunting and harvesting of precious timber. Ormsby and Kaplin (2005) also revealed that emigrants come to Masoala from other areas to log rosewood as they have no other means of earning an income. Pressure on natural resources in Madagascar's parks and reserves - each of which has its own complexities regarding management issues - comes from various groups, ranging from impoverished subsistence farmers to cunningly organised international timber dealers. Ormsby and Kaplin (2005) confirmed that precious timber is harvested from inside Masoala National Park and that the bulk of the wood is exported to international markets. They also allude to the challenging nature of any attempts to enforce existing laws, pointing out that park agents lack the authority to arrest people caught logging timber in protected areas. The terrain in both Masoala and Marojejy National Parks is exceptionally rugged, and the ratio of park rangers to loggers is hopelessly small - approximately one park employee per $100 \mathrm{~km}^{2}$ (Schuurman 2009).

One log of rosewood is ca. $196 \mathrm{~kg}$ (Stasse 2002). The logs are then transported by people from inside of the forests and then floated on rafts or carried on dugout canoes. They are then transported in trucks to ports where they are packed into containers (Débois 2009). The loaded containers in Vohémar weigh ca. 20 tons (an empty container is 2.2 tons). Larger

TABLE 1. Exportation of rosewood from Antalaha and Toamasina between July 2000 and June 2001 estimated from numbers given in Stasse (2002).

\begin{tabular}{|c|c|c|c|c|c|c|}
\hline \multirow[b]{2}{*}{ Month } & \multicolumn{2}{|c|}{ Port of Vohémar } & \multicolumn{2}{|c|}{ Port of Toamasina } & \multicolumn{2}{|c|}{ Totals Northeast } \\
\hline & Number of logs & Weight (tons) & Number of logs & Weight (tons) & Number of logs & Weight (tons) \\
\hline VII 2000 & 7,700 & 1,509 & 1,782 & 349 & 9,482 & 1,859 \\
\hline VIII 2000 & 8,669 & 1,699 & 9,732 & 1,908 & 18,401 & 3,607 \\
\hline IX 2000 & 15,091 & 2,958 & 4,168 & 817 & 19,259 & 3,775 \\
\hline X 2000 & 16,184 & 3,172 & 11,508 & 2,256 & 27,692 & 5,428 \\
\hline XI 2000 & 13,038 & 2,555 & 8,055 & 1,579 & 21,093 & 4,134 \\
\hline XII 2000 & 0 & & 0 & & 0 & \\
\hline | 2001 & 0 & & 8,877 & 1,740 & 8,877 & 1,740 \\
\hline || 2001 & 1,931 & 379 & 3,914 & 767 & 5,845 & 1,146 \\
\hline III 2001 & 3,547 & 695 & 9,608 & 1,883 & 13,155 & 2,578 \\
\hline IV 2001 & 7,350 & 1,441 & 425 & 83 & 7,775 & 1,524 \\
\hline V 2001 & 8,068 & 1,581 & 6,905 & 1,353 & 14,973 & 2,935 \\
\hline VI 2001 & 6,147 & 1,205 & 7,903 & 1549 & 14,050 & 2,754 \\
\hline TOTALS & 87,725 & 17,194 & 72,877 & 14,284 & 160,602 & 31,478 \\
\hline Estimated number of trees & \multicolumn{2}{|c|}{ ca. 43,500} & \multicolumn{2}{|c|}{ ca. 36,500} & \multicolumn{2}{|c|}{ ca. 80,000} \\
\hline
\end{tabular}


TABLE 2. Values from the 55 containers of 'legalized' illegally-logged rosewood exported from Vohémar (Iharana) on $31^{\text {st }}$ October 2009. The numbers have been obtained from a Cargo Manifest belonging to UAFL Mauritius; the weight declared may be underestimated as it is common practice, reported by Stasse (2002) who gives a mean weight of $196 \mathrm{~kg}$ per log.

\begin{tabular}{lcccc}
\hline $\begin{array}{l}\text { Shippers } \\
\text { GUERRA William }\end{array}$ & $\begin{array}{c}\text { Declared weight } \\
\text { (tons) }\end{array}$ & Number of logs & $\begin{array}{c}\text { Estimated } \\
\text { value }\end{array}$ & Destination \\
BEMATANA Martin & 180 & 1386 & $\$ 2,000,000$ & Beijing Yintuo, Hong Kong \\
NDAHINY Gregoire & 180 & 1080 & $\$ 2,000,000$ & Beijing Yintuo, Hong Kong \\
NDAHINY Gregoire & 270 & 2181 & $\$ 3,000,000$ & Beijing Yintuo, Hong Kong \\
CHAN HOY LANE & 90 & 705 & $\$ 1,000,000$ & China Meheco Traditional \\
BODY Thierry & 54 & 446 & $\$ 600,000$ & Shanghai Tong Sheng, Shanghai \\
\hline TOTALS & 215 & 1469 & $\$ 2,400,000$ & Zhyangjiagang Free Trade, Jianghsu \\
\hline
\end{tabular}

cranes in Toamasina port allow for the use of containers twice as large and able to accommodate double the weight of those used in Vohémar port. In most cases, a mature tree is divided into two logs. Using the above information it can be deduced that 17,194 tons of timber are made up of about 85,970 logs -in other words, an estimated 42,985 trees were sourced from the area's rainforests and shifted out of the country virtually unnoticed (until recently) by the international conservation community working in the protected areas of the Atsinanana World Heritage Site. The apparent sole exception was an article published by a research anthropologist (Patel 2007).

Local communities derive very little benefit from logging precious timber, despite the fact that it is an extremely demanding and labour-intensive activity (Stasse 2002, Patel 2007) People living around Masoala and Marojejy National Parks who are inclined to favour protection of these areas find themselves in a complicated predicament. The northeast has a per-humid seasonal climate, a largely rugged and mountainous geography that makes travel and access difficult, and minimal infrastructure, all of which limit tourism, long promoted as a potentially important alternative source of income. Ormsby and Mannle (2006) indicate that a maximum of 2,000 visitors come to Masoala annually, $78 \%$ of whom only go as far as the easily accessible Nosy Mangabe island reserve, where wildlife viewing is virtually effortless. Marojejy National Park has the capacity to cater for far fewer tourists (Bradt 2007).

Almost annually, the SAVA region is struck by violent tropical storms. When Cylone Hudah left 50,000 people homeless in April 2000 (Birkinshaw 2007), the inevitable result was a marked increase in tavy (slash and burn agriculture), hunting of wildlife for food, and more intensive harvesting of precious hardwoods (Ormsby and Kaplin 2005). Patel (2007) cites additional reasons for increased illegal logging in the SAVA region, including the devastating decline in the price offered for the main cash crop, vanilla, which fell from US $\$ 230$ to US \$ 25 per kg between 2003 and 2005 (Débois 2009). Its value is currently less than US $\$ 27$ per $\mathrm{kg}$ (Baillard 2009)

If the government or aid agencies were to allocate emergency funds to assist the people affected by cyclones this would probably only alleviate short-term problems and would therefore not be sufficient to create an opportunity for people who have just lost everything to re-establish themselves. Local residents are thus forced to draw even more heavily on natural resources within protected areas. This insidious cycle is likely to intensify as the projected impacts of global and regional climate change become increasingly apparent, and in particular as storm frequency and intensity increase (Hannah et al. 2008). These natural events are further compounded during times of political turmoil such as in 2002 and 2009, casting doubt over whether many of the conservation efforts in Madagascar - a donor-dependent country widely regarded as one of the world's foremost conservation priorities - have a chance of succeeding in the long-term (Rabesala Horning 2008).

Illegal selective logging for high-value timber species is by no means limited to Masoala and Marojejy National Parks. Similar, albeit thus far perhaps less intense, extraction of valuable trees from protected areas takes place throughout the country and timber is shipped out of most of the island's ports (Figure 1). Given that logging of precious timber has been problematic for many decades in Madagascar, one could question whether political turmoil is the main spark that sets off pillaging of valuable timber from protected areas, or alternatively whether the drive to exploit valuable and sought-after resources such as rosewood on legally public land might contribute to political turmoil, for instance when some members of the higher echelons of Malagasy society are excluded from benefiting from the lucrative trade in natural resources.

\section{CONCLUSIONS}

We conclude that the $11932 / 2000$ decree resulted in continuing illegal logging in Madagascar's protected areas, through the events of 2002 and up to the present (November 2009). A paucity of published information between 2000 and 2008 has not helped matters, though it is clear from the grey literature (e.g., Stasse 2002) that Madagascar's forests have suffered significantly during periods of political turmoil. The absence of proper studies - and therefore information necessary to have the appropriate legislation formulated and measures implemented - have allowed for this to happen again in 2009.

Illegal logging and export of rosewood taken from protected areas almost exclusively benefits the small number of individuals who organize and manage the trade and a few strategically placed persons in government. Regimes, it would seem, have a tendency to allow for 'exceptions' (the decrees) when it comes to legislation concerning export of precious timber, particularly during periods of political instability. Impoverished 
local people - those who suffer most due to weak governance and also sanctions - are virtually forced into a situation where they have to seek employment in the illegal logging industry.

The accelerating run now being made for Madagascar's precious wood is driven by a continually growing demand in the international market, particularly in China (Laurance 2008). Under President Marc Ravalomanana, Madagascar's previous government set a goal of legally protecting $10 \%$ of the country's area. One would have hoped and expected that more stringent measures would be in place to conserve what remains of Madagascar's dwindling forests. Even following a regime change, no government should permit - let alone condone or encourage - illegal logging in its parks and reserves. Yet this has happened for decades in Madagascar under successive governments, although perhaps never before at such a frenzied pace as we are witnessing today (Lough 2009, Wilmé et al. 2009).

What can be done to alleviate the current situation? We proposed that (i) The identities of all exporters, of all members of the 'timber mafia', of buyers and of shipping companies should be publically revealed; (ii) While it may be a time-consuming process, perhaps all species of Dalbergia should receive protection under CITES. Detailed taxonomical work needs to be completed by botanists and the information shared with forestry specialists, so published knowledge on populations of 'target' species is accessible and can be used for the formulation of policies geared to protect what remains of Madagascar's forests; (iii) There is a need for an increase in the number of park staff as well as in the level of authority granted to staff responsible for patrolling parks, so people caught in the act of illegal logging within protected areas can be dealt with appropriately.

\section{ACKNOWLEDGMENTS}

We would like to thank our sources, most of whom have placed their lives at risk gathering information presented in this paper. Three anonymous reviewers are acknowledged for their comments and feedback.

\section{REFERENCES}

Baillard, D. 2009. Commerce. La vanille va mal. Tribune. Édition du 23 septembre 2009. <http://www.madagascar-tribune.com/La-vanille-vamal,12774.html> accessed 31 October 2009.

Ballet, J. \& Rahaga, N. 2009. Impact Économique des Arrêtés autorisant les Exportations de Bois Précieux à Madagascar. Unpublished report to PGM-E/GTZ.

Birkinshaw, C. and Randrianjanahary, M. 2007. The effects of cyclone Hudah on the forest of Masoala Peninsula, Madagascar. Madagascar Conservation \& Development 2: 17-20.

Bosser, J. \& Rabevohitra, R. 1996. Taxa et noms nouveaux dans le genre Dalbergia (Papilionaceae) à Madagascar et aux Comores. Bulletin du Museum national d'Histoire naturelle, $4^{\mathrm{e}}$ sér., 18: 171-212.

Bosser, J. \& Rabevohitra, R. 2005. Espèces nouvelles dans le genre Dalbergia (Fabaceae, Papilionoideae) à Madagascar. Adansonia, Sér. 3, 27, 2: 209-216.

Bradt, H. 2007. Madagascar. Bradt Travel Guide, Chalfont St. Peter, U.K.

Débois, R. 2009. La fièvre de l'or rouge saigne la forêt malgache. Univers Maoré 13: 8-15.

Du Puy, D. J., Labat, J.-N., Rabevohitra, R., Villiers, J.-F., Bosser, J. and Moat, J. 2002. The Leguminosae of Madagascar. Royal Botanic Gardens, Kew, U.K.

Ganzhorn, J. U. and Sorg, J.-P. (Eds.) 1996. Ecology and Economy of a Tropical Dry Forest in Madagascar. Primate Report Special Issue 46, 1: 1-382.

Goldstein, A., Pinaud, N., Reisen, H. and Chen, X. 2006. The rise of China and India: What's in it for Africa? OECD Publishing.
Hannah, L., Dave, R., Lowry II, P. P., Andrianarisata, M., Cameron, A., Hijmans, R., MacKinnon, J., Randrianasolo, H. H., Andriambololonera, S., Razafimpahanana, A., Randriamahazo, H., Randrianarisoa, J. Razafinjatovo, P., Raxworthy, C., Schatz, G. E., Tadross, M. and Wilmé, L. 2008. Climate change adaptation for conservation in Madagascar. Biology Letters 4: 590-594. (doi:10.1098/rsbl.2008.0270)

Kozak, R. and Canby, K. 2007. Why China prefers logs. Explaining the prevalence of unprocessed wood in China's timber imports. Forest Trends 9: $1-5$.

Laurance, W. F. 2008. The need to cut China's illegal timber imports. Science 319: 1184-1185. (doi:10.1126/science.319.5867.1184b)

Maka, A. Exploitation illicite de bois de rose. Parc national de Masoala ravagé. La Vérité 19 août 2009. < http://www.laverite.mg/actualitesa-madagascar/exploitation-illicite-de-bois-de-rose-parc-national-demasoala-ravage.html> accessed 20 August 2009.

Lough, R. 2009. Madagascar accused of profiting from illegal timber. Reuters 3 October 2009

Ormsby, A. and Kaplin, B. A. 2005. A framework for understanding community resident perceptions of Masoala National Park, Madagascar. Environmental Conservation 32, 2: 156-164. (doi:10.1017/ S0376892905002146)

Ormsby, A. and Mannle, K. 2006. Ecotourism benefits and the role of local guides at Masoala National Park, Madagascar. Journal of Sustainable Tourism 14, 3: 271-287. (doi:10.1080/09669580608669059)

Patel, E. R. 2007. Logging of rare rosewood and palisandre (Dalbergia spp.) within Marojejy National Park, Madagascar. Madagascar Conservation \& Development 2, 1: 11-16.

Phillipson, P. B., Schatz, G. E., Lowry II, P. P. and Labat, J.-N. 2006. A catalogue of the vascular plants of Madagascar. In: Taxonomy and Ecology of African Plants: Their Conservation and Sustainable Use. S. A. Ghazanfar and $H$. J. Beentje (eds.), pp 613-627. Proceedings XVIIth AETFAT Congress. Royal Botanic Gardens, Kew.

Rabesala Horning, N. 2008. Strong support for weak performance: Donor competition in Madagascar. African Affairs 107: 405-431. (doi:10.1093/ afraf/adn036)

Razafindramiadana, L. 2009. Trafic de bois de rose. Pas de rapatriement de devises. L'Express de Madagascar 31 octobre 2009. <http://www. lexpressmada.com/display.php? $p=$ display $\&$ id $=30755>$ accessed 31 October 2009

Schatz, G. E. 2001. Generic Tree Flora of Madagascar. Royal Botanic Gardens, Kew.

Schuurman D. 2009. Illegal logging of rosewood in the rainforests of northeast Madagascar. TRAFFIC Bulletin 22, 2: 49

Stasse, A. 2002. La Filière Bois de Rose. Région d'Antalaha - Nord-est de Madagascar. Unpublished Master's thesis, Université de Montpellier, France.

Wilmé, L., Schuurman, D., Lowry II, P. P. and Raven, P. H. 2009. Precious trees pay off - but who pays? Poster prepared for the World Forestry Congress in Buenos Aires, Argentina, 18-23 October 2009.

\section{SUPPLEMENTARY MATERIAL.}

AVAILABLE ONLINE ONLY:

Poster titled 〈Precious Trees pay off - but who pays? prepared by Lucienne Wilmé, Derek Schuurman, Porter P. Lowry II and Peter $\mathrm{H}$. Raven for the World Forestry Congress held in Buenos Aires, October 2009. 